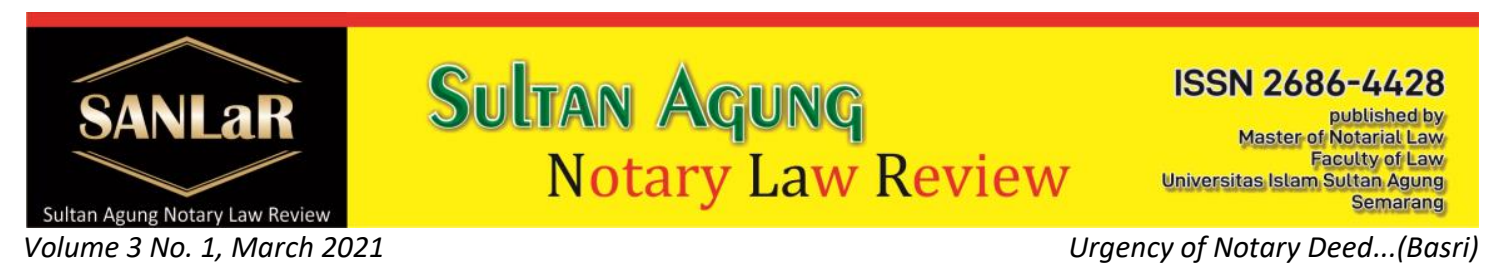

\title{
Urgency of Notary Deed (Deed of Work Agreement Between Worker \& Employer)
}

\author{
Basri $^{*}$ \\ *) Student Master of Notary Law, Faculty of Law, Universitas Islam Sultan Agung \\ Semarang, Indonesia, E-mail: bungboy15@gmail.com
}

\begin{abstract}
Labor law is the law that regulates the relationship between workers, employers and the government. Labor law functions to protect the interests of workers from the unlimited power of the employer/entrepreneur (Soepomo, 1999: 8-9). To avoid abuse in the relationship between employers and workers, it is necessary to intervene by the government through statutory regulations. This study aims to determine how urgent the work agreement deed is and how important it is to make a work agreement deed for the world of labor. This research uses a sociological juridical approach, research conducted on the real reality of workers, employers and the role of the government in building better labor laws. Based on research at the Manpower Office of Kendari City, the Manpower Office of Southeast Sulawesi Province and workers, there are several violations of labor regulations and also violations against workers so that the importance of work agreement deeds is that the rights and obligations of both parties can be known together and also notary deeds can be authentic evidence for both parties, and also for workers and employers to be more obedient and obedient to the rules concerning manpower and the urgency of a notary deed is for the development of labor law to make it better in the future, and to minimize labor violations.
\end{abstract}

Keywords: Urgency; Notary Deed; Work Agreement.

\section{Introduction}

Labor or employment issues are still unsolved and attract ${ }^{1}$ the attention of many parties. Labor issues such as conflicts between workers and employers, such as cases of labor conflicts, violence, fraud, arbitrary dismissal (termination of employment rights), non-standard wages, violations of working hours, violations of leave, violations of exclusion of workers In the pension program, there are no company regulations made by employers that are given to workers, there is no labor organization formed by employers and workers in the company, there are no work contracts made by both parties, etc. so that workers sometimes do not know their rights. and obligations while they are working and this is very detrimental to the workers. In the laws and regulations relating to manpower, the rights and obligations of each party have been explained, namely the rights and obligations of employers and workers, but it seems as if these laws are sometimes not obeyed and are not implemented as the article by article has listed in it as well as existing government agencies such as the manpower

\footnotetext{
${ }^{1}$ Abetnego tarigan dkk, panduan bantuan hukum di indonesia, jakarta, yayasan obor indonesia. (2014). p. 152.
} 
office which functions to oversee labor and impose sanctions on companies that do not comply with the rules so that there are no violations against workers and so that laws and regulations relating to employment can be implemented properly and maximum, but in reality there are still frequent violations of workers' rights.

That is the importance of an agreement to bind both parties. We often hear the name of the Labor Union or Worker Union which is said to be able to help solve these problems through their assistance, one of which is through the Collective Labor Agreement. Based on the general provisions of Article 1 point 17 of Act No. 13 of 2003 concerning Manpower, namely: "A Worker Union or Labor Union is an organization formed from, by and for workers both in the company and outside the company, which is free, open, independent. , democratic, and responsible to fight for, defend and protect the rights and interests of workers/labor and improve the welfare of workers/labor and their families". The occurrence of strife between humans is something that often happens. Therefore, what is important and must be done is a way to prevent or minimize the dispute or reconcile those who are in dispute.

Therefore, the authors consider that the existence of a notary deed (work agreement deed) which is made between workers and the company as legal protection for workers and so as not to occur or reduce human rights violations against workers, which in the work agreement deed will regulate the rights. and obligations of both parties and will also regulate strict sanctions if one party does not comply with the contents of the deed. Legal protection for humans or workers is the fulfillment of basic rights inherent and protected by the constitution as regulated in Article 27 paragraph (2) of the 1945 Constitution "Every citizen has the right to work and a decent living for humanity", and Article 33 paragraph (1) which states that "the economy is structured as a joint effort on the basis of kinship". In this case, a violation of basic rights protected by the constitution is a violation of human rights.

Development in the manpower sector Development in the manpower sector is part of the development of the Indonesian human being as a whole, as mandated by Pancasila and the 1945 constitution. This development is to increase the dignity, dignity and dignity of the workforce as well as realizing a prosperous, just, prosperous and equitable society both materially. and spiritual. ${ }^{2}$

\section{Research Methods}

This research is intended to produce a reconstruction of new thoughts or ideas and theories, to perfect existing or completely new thoughts and ideas and theories. This research is to reveal the role of the state, government and society and their obstacles in the application of Act No. 13 of 2003 on manpower. This study uses a sociological juridical approach. The sociological juridical approach method is a research carried out on the real reality of workers and employers as well as the role of government in building good and fair employment with the intent and purpose of fact-finding, which

\footnotetext{
${ }^{2}$ Dr. Suratman, S.H., M.Hum. pengantar hukum ketenagakerjaan indonesia, Depok: Pt Rajagrafindo persada. ( 2019). p. 7.
} 
then leads to identification (problem-identification) and at finally leading to problem solving (problem-solution) This type of research is empirical juridical research, which is research based on the prevailing laws and regulations, as well as by harmonizing and describing real problems and conditions regarding the implementation of law number 13 of 2003 concerning manpower. This means that this research describes how a legal provision is in the context of theory. -Legal theory, which in its presentation describes various issues related to the application of labor regulations based on the value of justice.

\section{Results and Discussion}

\subsection{In the explanation of Article 1230 of the Civil Code}

The legal requirements of an agreement in general can be found which can be seen as follows:

Regarding the legal requirements of an agreement regulated in article 1320 of the Civil Code which states that for the validity of agreements, four conditions are needed, namely that they agree to bind themselves: the ability to make an engagement: $a$ certain thing: and a lawful cause. The first and second conditions mentioned above are called subjective conditions, because they involve the people who entered into the agreement, while the third and fourth conditions are called objective conditions, because they involve the object of the promised event, ${ }^{3}$ including: agreement, skills, certain things, and causes (causa) are lawful the legal terms of the work agreement according to law.

Corresponding article 52 of the Manpower Law, the work agreement must be made on the basis of an agreement between the two parties, the ability or ability to take legal actions, the existence of the work that was agreed upon, the work that was promised does not conflict with public order, morality, and the prevailing laws and regulations. That is, employers and workers agree on the things that were promised and improve themselves. Both parties must be competent to make agreements, be sane (no mental disorder), and are of legal age or at least 18 years of age. The work agreement must also have an object, namely the work that was agreed upon, which fulfills the requirements as lawful work, does not conflict with law, public order, and morality.

Based on the results of research at the Southeast Sulawesi Provincial Manpower Office:

\section{Industrial relations disputes}

In the field of industrial relations disputes, there were 29 industrial relations cases from January to December 2019 involving 29 companies and 650 workers in various companies, including in the fields of mining, trade, plantation, gas, services, fisheries, etc. In which there are various kinds of disputes, including cases of termination of workers' rights (PHK), violations of collective agreement rights (PB). Even HJ.

\footnotetext{
${ }^{3}$ I Ketut Oka Setiawan. Hukum Perikatan. Jakarta Timur: Sinar Grafika. (2018). Third Edition, p. 60-61.
} 
Fatmawati, $\mathrm{SH}$, as the intermediate functional mediator of Industrial Relations (HI) revealed that 32 cases since 2019, of which 2 were transferred to supervision and 1 worker was absent (absent from the call to the labor office to solve the problem), in these 32 cases, eight (8) among them have made recommendations and twenty three (23) others have made mutual agreements and one (1) is still in the process of mediation $\mathrm{HJ}$. Fatmawati also explained that most of the cases handled by the mediators were cases of termination of employment (PHK) by companies.

In fact, not a few employers pay workers 'salaries with wages below the provincial minimum wage or the city minimum wage, so if there is a termination of employment, the mediator in issuing recommendations to calculate workers' rights must be based on the city minimum wage or the provincial minimum wage. As for the obstacles when mediating between workers and employers is the absence of company regulations and/or collective work agreements between workers and employers, while companies that have company regulations or collective labor agreements are no longer valid because the law requires that this be extended. every two (2) years and if it is not extended then it is deemed invalid, so that the rights and obligations of workers and employers can only be seen in labor Act No. 13 of 2003.

Furthermore, HJ. Fatmawati. SH, also said that the recommendation issued by the mediator cannot be implemented automatically if there are parties who object to the recommendation and the recommendation does not have the power of execution. Furthermore HJ. Fatmawati, $\mathrm{SH}$, said that almost all companies that are mediated do not have company regulations or do not make work agreements that serve as guidelines for workers to know their rights and obligations, while companies that have company regulations do not share these regulations with their workers.

\section{The field of industrial relations and labor inspection}

Based on data from the industrial relations and labor inspection sector, there are seven thousand two hundred twenty seven $(7,227)$ companies and ninety thousand eight hundred twenty-seven thousand $(90,927)$ workers registered with the Southeast Sulawesi Manpower Office in 2018 but employers who report According to the data obtained from the manpower office in 2019, the number of companies based on the 2019 mandatory labor report in Southeast Sulawesi was only one hundred and sixty one (161) companies required to report with a total of four thousand four hundred ninety five (4495) workers and the rest as many as seven thousand sixty six $(7,066)$ companies did not report back their companies.

Even three (3) large companies in Kendari city that are engaged in hospitality, which is the place where the author's research is not registered, is obliged to report the company. That companies located in Southeast Sulawesi are also disobedient to the labor law, especially for ratifying company regulations, as can be seen in data obtained from the Southeast Sulawesi Manpower Office in 2019, only 15 companies ratified their company regulations. Based on the statement of Bpk. Amrullah Sip. MM., as the head of the section of labor law enforcement in the field of manpower and labor inspection and occupational health safety, Southeast Sulawesi province, 
based on the findings of labor inspection in the field, there were labor violations in which there were two hundred and eighty eight (288) companies with the number of violations of eight hundred and seventy (870) including violations: wage protection norms, mandatory report kk (employment), wage norms, wkwi norms (working time and rest time), $\mathrm{K} 3$ norms (safety, health, work), Jamsostek norms, rest time norms, work relations norms, facilities and facilities supervision norms, work accidents, fire extinguishers (light fire extinguishers), must report sales vacancies, Meanwhile, the sanctions imposed by the labor inspection sector are the creation of an inspection note containing a warning about violations of the labor law. Based on the results of research at the Kendari City Manpower Office Industrial relations disputes at the Kendari City Manpower Office there were twenty six (26) cases of dismissal that were mediated (tripartite) from January to December 2019 involving twenty-six (26) companies and thirty-four (34) workers present in various companies and produced four (4) recommendations, four (4) PB (mutual consent). There are only twenty companies that register their company regulations in 2019 with a total number of employees of eight raus four (804). Based on the results of research at the notary office in Kendari city.

Mr. Sudirman, SH M.Kn as the head of the Kendari city notary association regarding the urgency of the notary deed between workers and employers as the optimization of Act No. 13 of 2003 concerning manpower. The law regulates the rights and obligations of workers and employers, but it is not always complied with by all parties. because the name of a notary deed is definitely authentic and has perfect evidentiary power when compared to an underhand deed or an agreement made only by both parties (workers and employers), notary deed (work agreement deed) is indeed very good if it is made by both both parties (workers and employers) but until now no one has come and asked for a notary deed (work agreement deed), this is because the law does not require every worker to have a notary deed (work agreement deed). If in the future there is a work agreement deed, there should first be rules governing it so that the parties (workers and employers) feel they have a legal obligation to make a work agreement deed, a work agreement deed can also minimize violations against workers if the classes in the deed are made properly and correctly without partiality to either party. Work agreement deeds can also minimize violations against workers if the classes in the deed are made properly and correctly without taking sides with either party. Work agreement deeds can also minimize violations against workers if the classes in the deed are made properly and correctly without taking sides with either party.

This is indeed very good for the development of labor law in the future and also as a protection for workers so that they are more aware of their rights and obligations in their place of work and also notary deeds (work agreement deeds) will be more easily used as evidence in court in case of labor disputes, with the existence of a notary deed (work agreement deed) can provide more legal certainty. Results of interviews with several workers. 
There are several employees at the companies where the research is conducted who are willing to be interviewed but their names cannot be mentioned in this paper because the employee has not received permission from the company to provide information regarding the company where he works and also the employee is afraid that later he will be fired by the company. Which in short, the employee revealed that our rights and obligations as workers who have only recently been in writing for a few months are not in writing so we who work here do not know about it, even our wages are some of the employees here who are only seven (7) to eleven (11) months work is still far below the city minimum wage or provincial minimum wage which is currently (ump 2019 IDR 2,351,087 Governor Regulation No. 69 of 2018 and Umk 2019 IDR 2,551,463 Governor Regulation No. 78 of 2018), Besides salary (IDR $1,650,000 /$ month) we do not get any other form of allowance and also about the procedure for taking leave we also do not understand, especially we who have not been contracted, and also especially female workers do not dare to take menstrual leave for fear of termination of work If you take too much leave, whether it's menstrual leave or holidays without notification from the entrepreneur, the hotel is divided into several parts, some work as hoskiping, front office, fb service, kitchen, staff ofice, publick area, department store, engineering, security, manager on duty, sales marketing, etc. In our place of work, there are those who work for three (3) months directly on a contract, while we have worked for almost a year and have not yet signed a contract even though we are one management, We hope that employers or companies make collective labor regulations or work contracts even if necessary a notary deed (work agreement deed) is made so that we can know our rights and obligations as workers, especially if there is a problem or something related to our work we can know what to do What. Previously the author aimed to conduct research in three (3) places, namely large companies in Kendari city, because these companies are large companies that employ many workers so that the author is interested and curious whether all workers have got their rights as already regulated in the labor law, however, these companies refuse that the author does not conduct research on these companies. So there are many questions for companies to which research is unanswered.

\subsection{The importance of making a Notary Deed (Deed of Employment Agreement) between workers and the employer}

We can see from the results of the above research that there have been many violations against workers so it is very important if there is an agreement made between the worker and the employer to regulate the certainty of the work relationship between the two parties, especially if the agreement is stated in a notary deed which it is authentic In the labor law, it has clearly regulated the rights and obligations between workers and employers, we can see that the proof of authentic letters under the hands of a letter is far different where authentic letters have perfect proof, so that notary deed (deed of employment agreement between workers and employers is very It is important for workers to know their rights and obligations and can also be a good guide for employers and workers, and can also be an authentic hold for both parties. 


\subsection{The Urgency of the Notary Deed between Workers and Employers}

The urgency of a notary deed (deed of work agreement between the employee and the employer) is so that there is no more fooling and oppression of workers, as can be seen above that there have been many violations committed by the employer against workers in various fields, whether it is in in the field of occupational health and safety, leave rights/vacation rights, layoffs, wages, pension programs, etc. This proves that employers are not obedient and do not implement laws relating to manpower. The government should think about making a binding rule for workers and employers, for the development of better labor laws in the future.

\section{Closing}

The importance of a notary deed (deed of work agreement between workers and employers) is that the rights and obligations between workers and employers can be known together and also notary deed (deed of work agreement between workers and employers) can be authentic evidence for both parties, and also so that workers and employers are more obedient and obedient to the regulations concerning manpower and urgency of a notary deed (deed of work agreement between workers and employers) is for the development of labor law to make it better in the future, and to minimize violations in the world of manpower.

\section{References}

Books:

[1] Abetnego Tarigan dkk, panduan bantuan hukum di indonesia, jakarta, yayasan obor indonesia. (2014).

[2] Dr. Suratman, S.H., M.Hum. pengantar hukum ketenagakerjaan indonesia, Depok: Pt Rajagrafindo persada. ( 2019)

[3] I Ketut Oka Setiawan. Hukum Perikatan. Jakarta Timur: Sinar Grafika. (2018). Third Edition.

Data from research:

[1] Attachment data on company violations in Southeast Sulawesi province.

[2] Company data based on the 2019 mandatory labor report for Southeast Sulawesi province.

[3] Data from Kendari City Manpower Office is related to data on trade unions/labor unions for September 2019.

[4] Data from the Kendari City Manpower Office on companies that registered company regulations from January to December 2019.

[5] Data on the number of companies and workers registered in Southeast Sulawesi Province.

[6] Membership data of the Southeast Sulawesi province of workers/labor unions. 
[7] Register of cases of industrial relations disputes at the Kendari City Manpower Office in 2019.

[8] Registration data for the legalization of company regulations.

[9] Report on the settlement of industrial relations disputes at the Manpower Office of Southeast Sulawesi Province. 